\title{
PRODUK LOKAL SEBAGAI KEKAYAAN NUSANTARA : PENGUATAN DESA- KOTA MELALUI POLA ALIRAN SUMBERDAYA WILAYAH
}

\author{
Siti Nuurlaily Rukmana ${ }^{1)}$ dan Moch. Shofwan ${ }^{2)}$ \\ ${ }^{1)}{ }^{2)}$ Program Studi Perencanaan Wilayah dan Kota, Universitas PGRI Adi Buana Surabaya \\ Email : nuurlailyrukmana@gmail.com \\ Email : shofwan.moch@gmail.com
}

\begin{abstract}
Abstrak
Kesenjangan antara desa dan kota merupakan salah satu pemicu terjadinya urbanisasi. Fenomena ini dapat diminimalkan dengan penguatan hubungan antar sektor desa dan kota melalui interkoneksinya antara perekonomian dan sosial sehingga dapat menciptakan pertumbuhan regional yang berkelanjutan. Tujuan penelitian ini untuk mengetahui potensi pola aliran sumberdaya wilayah Pekalongan. Tercapainya tujuan penelitian ini terdapat beberapa tahapan yaitu: deliniasi wilayah studi, menganalisis karakteristik/isu-isu keterkaitan desa-kota wilayah Pekalongan serta menilai dan menganalisis potensi pola aliran wilayah Pekalongan. Berdasarkan hasil analisis (1) wilayah pekalongan dibagi menjadi 3 zona yaitu perkotaan, pinggiran dan perdesaan (2) untuk karakteristik wilayah pekalongan memiliki tiga sektor unggulan yaitu sektor batik, perikanan dan pertanian. Dari tiga sektor ini memiliki keterkaitan antar wilayah yaitu sektor batik, sedangkan untuk perikanan (zona perkotaaan-pinggiran) dan untuk pertanian hanya (zona pinggiran-perdesaan); (3) serta berdasarkan hasil analisis pola aliran di Pekalongan yaitu zona perkotaan memiliki pola aliran yang kuat antar sub zona dimana zona ini tidak hanya digunakan sebagai tempat produksi batik tetapi juga sebagai tempat pemasaran pusat batik di Wilayah Pekalongan. Hal ini juga dibuktikan dari 50\% pengrajin batik berasal dari luar Pekalongan. Sedangkan untuk sektor perikanan dan pertanian memiliki keterkaitan antar zub zona $30 \%$ dari masing masing produk.
\end{abstract}

Kata Kunci : Desa Kota, Flow analysis, Urbanisasi, Pekalongan

Abtract
The gap between rural and urban creates urbanization. This phenomenon can be minimized by strengthen rural - urban through the interconection between economic and social aspect in order to create a sustainable regional growth. The aim of this research to determine the potential pattern of natural resource in Pekalongan-Central Java. To achieved the goal of this research, there are some objective i.e. delineation of study area, analyzing the characteristics of rural - urban linkage, assessing and analyzing of natural resource potential flow. Therefore, the result of this research are: $1^{\text {st }}$, the delineation area is divided 3 zones i.e. urban, peri-urban and rural. $2^{\text {nd }}$, the characteristic of rural urban linkage has three leading sectors such as Batik, fisheris and agriculture. $3^{\text {rd, }}$, the analysis of natural resouce flow is shown that urban zone has a strong flow pattern among other sub-zone. In one hand, urban-zone is not only used as a place of Batik production but also as a marketing center in Pekalongan. While, for labor from outside Pekalongan by 50\%. In the other hand, the fisheris and agriculture sector have linkages between other sub zones, approximately $30 \%$ of each product.

Key words : Rural-Urban,, Flow analysis, Urbanization, Pekalongan

\section{PENDAHULUAN}

Permasalahan yang terjadi di dunia perencanaan salah satunya adalah kesenjangan antara desa dan kota. Kesenjangan ini terjadi karena adanya kecenderungan masyarakat yang berfikir bahwa peluang untuk bekerja dikota lebih besar dibandingkan tinggal di desa. Salah satu buktinya yaitu meningkatnya penduduk perkotaan di dunia pada tahun 2014 sebesar 54\% dari total penduduk global (WHO, 2015). Hal ini tentunya berdampak negatif ketika laju urbanisasi semakin tinggi, misalnya adanya alih fungsi lahan khususnya di kawasan perdesaan, meningkatnya angka kemiskinan dan ketahanan pangan yang menurun. Fenomena ini dapat diminimalkan dengan penguatan hubungan antar sektor desa dan kota melalui interkonerksinya antara perekonomian dan sosial sehingga dapat menciptakan pertumbuhan regional yang berkelanjutan.

Pertumbuhan regional yang berkelanjutan dapat dilakukan dengan cara pembagian peran antara desa dan kota (Mc.Gee, 2008). Hal ini dilakukan agar meminimalisir terjadinya urbanisasi, karena pada intinya pertumbuhan 
wilayah lebih menekankan pada kesinergian hasil dari peran masing-masing wilayah. Seperti yang dijelaskan oleh Lynch (2005) bahwa kawasan perdesaan dan perkotaan memiliki perspektif yang berbeda yaitu dari segi perspektif perdesaan memiliki karakteristik yaitu sebagian aktifitasnya adalah pertanian dan sebagai tempat bahan material dalam memproduksi hasil produk pertanian. Sedangkan dari segi perspektif perkotaan yaitu sebagai tempat pemasaran hasil produk pertanian serta sebagai tempat pelayanan.

Pekalongan dikenal sebagai kota batik. Pernyataan ini di dukung dalam dokumen RTRW Kota Pekalongan (2009-2029) dan RTRW Kabupaten Pekalongan (2011-2031 bahwa tujuan penataan ruang di pekalongan lebih fokus pada kegiatan industri. Untuk kota pekalongan lebih fokus pada industri batik dan hasil pengolahan ikan (minapolitan) sedangkan untuk kabupaten pekalongan fokus pada sentra pengembangan produk industri dan perdagangan dengan mempertahankan pertanian. Kegiatan industri di Pekalongan tentunya berdampak positif yaitu dengan memberi kesempatan kepada masyarakat lokal dan sekitarnya untuk berkerja.

Namun, permasalahnnya dalam perkotaan kebanyakan remaja lebih memilih untuk bekerja di pekerjaan lain bukan sebagai tenaga kerja batik dan ironisnya para tenaga kerja batik yang sudah berumur belum mampu mentransfer keterampilan dengan maksimal untuk generasi mereka. Sehingga untuk memenuhi karyawan di kota Pekalongan, beberapa karyawan diambil dari Pekalongan regional. Hal inilah yang memicu terjadinya migrasi antara kota pekalongan dengan kabupaten pekalongan maupun dari luar pekalongan (seperti Kabupaten Batang). Di sisi lain, wilayah Kabupaten Pekalongan memiliki banyak daerah perdesaan yang kegiatan utamanya adalah pertanian. Kegiatan pertanian terletak di sebelah selatan dari Pekalongan. Daerah perdesaan Pekalongan ini tidak hanya merupakan salah satu pemasok tenaga kerja untuk kegiatan industri di kota Pekalongan malainkan sebagai pemasok bahan baku kegiatan industri termasuk industri makanan. Dari beberapa masalah hubungan desa-kota wilayah Pekalongan bahwa kegiatan ekonomi didominasi di daerah perkotaan dibandingkan daerah perdesaan. Salah satu bukti yaitu perkembangan industri di kota pekalongan baik industri batik dan perikanan dapat di dukung dengan perbaikan infrastruktur.
Sebaliknya, Di daerah perdesaan yang terletak di sebelah selatan dari Pekalongan menjadi daerah yang belum berkembang karena minimnya pembangunan dan kurangnya kebijakan yang mendukung dari pemerintah, terutama untuk mendukung kegiatan pertanian.

Tujuan penelitian ini (1) menentukan klasifikasi wilayah melalui proses deliniasi (2) menganalisis karakteristik \& isu-isu potensi wilayah pekalongan dan (3) menilai dan menganalis potensi pola aliran (Potential flow analysis) sumberdaya wilayah di Pekalongan. Penelitian ini fokus Pekalongan Raya dimana untuk Kota Pekalongan terdiri dari 4 kecamatan dan 12 kecamatan di Kabupaten Pekalongan. Untuk letak geografisnya terletak di pesisir sebelah utara Provinsi Jawa Tengah. Adapun batas administrasi pada penelitian ini sebagai berikut:
Utara : Laut Jawa
Barat : Kabupaten Pekalongan
Selatan : Kabupaten Pelakongan dan Kabupaten Batang
Timur : Kabupaten Batang

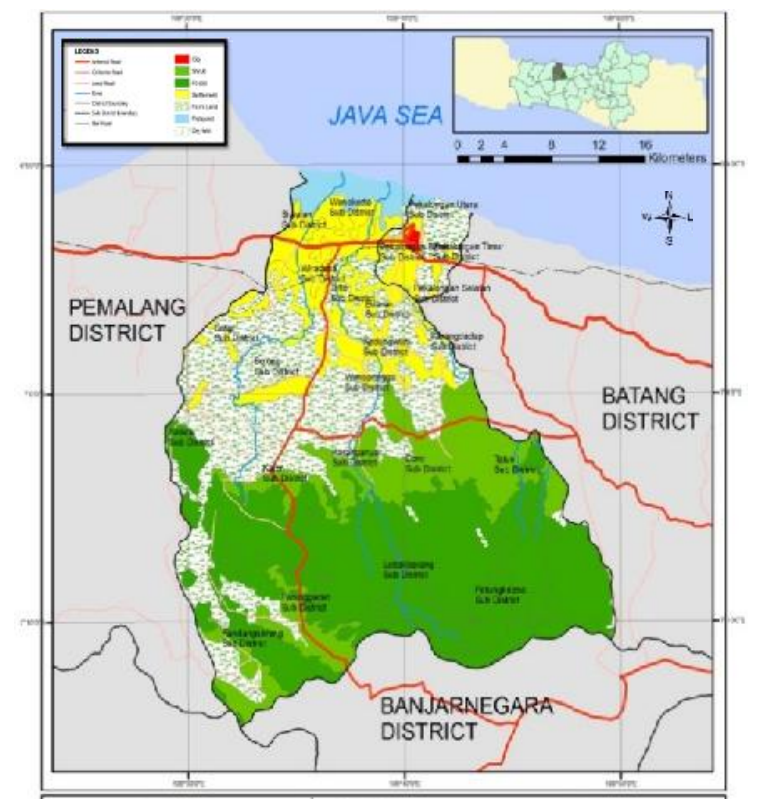

Gambar 1. Peta Wilayah Studi

\section{METODOLOGI}

\section{1) Pengumpulan Kebutuhan Data}

Kebutuhan data merupakan serangkaian data-data yang diperlukan untuk melakukan analisis sehingga dapat mencapai tujuan yang diharapkan. Pengumpulan kebutuhan data dapat dilihat pada tabel 1 . 
Tabel 1 Pengumpulan Kebutuhan Data

\begin{tabular}{|c|c|c|}
\hline $\begin{array}{l}\text { Informasi dan } \\
\text { Kebutuhan Data }\end{array}$ & Sumber & Tipe Data \\
\hline $\begin{array}{l}\text { Deliniasi kawasan } \\
\text { perkotaan dan } \\
\text { perdesaan } \\
\text { melalui: }\end{array}$ & $\begin{array}{l}\text { PODES (potensi } \\
\text { desa), aksessibilitas, } \\
\text { tingkat kepadatan } \\
\text { dan luas lahan } \\
\text { terbangun }\end{array}$ & $\begin{array}{l}\text { Data } \\
\text { sekunder }\end{array}$ \\
\hline $\begin{array}{l}\text { Menganalisis } \\
\text { karakteristik dan } \\
\text { penguatan } \\
\text { hubungan desa- } \\
\text { kota melalui pola } \\
\text { potensi } \\
\text { sumberdaya } \\
\text { wilayah }\end{array}$ & $\begin{array}{ll}\text { 1. } & \text { Sektor batik } \\
\text { 2. } & \text { Sektor } \\
\text { pertanian } \\
\text { 3. } & \text { Sektor } \\
\text { perikanan }\end{array}$ & $\begin{array}{l}\text { Data } \\
\text { sekunder }\end{array}$ \\
\hline
\end{tabular}

\section{2) Metode Analisis}

Metode analisis yang digunakan pada penelitian ini adalah deskriptif kuantitatif.

A. Analisis Deskriptif

Analisis deskriptif dapat digunakan untuk:

a. Mengetahui karakteristik wilayah studi, dimana difokuskan pada tiga sektor unggulan di Pekalongan seperti sektor batik, perikanan dan pertanian.

b. Menilai isu-isu keterkaitan antar zona. Dimana pada penelitian ini dibagi menjadi 3 zona (perkotaan, pinggiran dan perdesaan).

\section{B. Analisis Kuantitatif}

Analisis kuantitatif dapat digunakan untuk:

a. Deliniasi wilayah studi dilakukan berdasarkan skoring pada masing masing kriteria (seperti PODES, aksesbilitas, kepadatan, persentase lahan terbangun)

b. Keterkaitan desa kota melalui analisis potensi pola aliran sumberdaya wilayaha Pekalongan

\section{HASIL DAN PEMBAHASAN}

\section{1) Deliniasi Wilayah Studi}

Proses deliniasi wilayah studi antara kawasan perkotaan dan perdesaan dengan menggunakan beberapa kriteria yaitu: Podes (potensi desa), hirarki jalan, kepadatan penduduk dan luas lahan terbangun. Kemudian kriteria ini dilakukan pada masing-masing desa di wilayah studi menggunakan pembobotan di ArcGis (Tabel 2) (Gambar 2)
Tabel 2 Proses Delineasi

\begin{tabular}{ccccc}
\hline No & Variabel & Bobot & \multicolumn{1}{c}{ Kondisi } & Skor \\
\hline 1. & PODES & $25 \%$ & Perkotaan & 5 \\
& & & Perdesaan & 1 \\
2. & Aksessibilitas & $20 \%$ & Arteri & 5 \\
& & & Kolektor & 3 \\
& & Lokal & 2 \\
3. & Kepadatan & \multirow{2}{*}{$25 \%$} & $9158-$ & 5 \\
& & & $13713 / \mathrm{km}^{2}$ & \\
& & $4602-$ & 3 \\
& & $9157 / \mathrm{km}^{2}$ & \\
4. & Lahan & \multirow{2}{*}{$30 \%$} & $50-4601 / \mathrm{km}^{2}$ & 1 \\
& Terbangun & & $20.61-87.84 \%$ & 5 \\
& & & $1-20.62 \%$ & 1 \\
\hline
\end{tabular}

Sumber: Analisis, 2015

Keterangan : Untuk variabel kepadatan dan lahan terbangun diklasifikasikan menggunakan metode interval kelas sesuai dengan kelasnya:

\section{$\underline{\text { Nilai tertinggi - Nilai terendah }}$}

Berdasarkan hasil analisis maka didapatkan hasil deliniasi dengan tiga zona yaitu kawasan perkotaan, pinggiran/peri urban, dan perdesaan (Tabel 2) (Gambar 2)

Tabel 2. Hasil Analisis Deliniasi Area

\begin{tabular}{ccll}
\hline \multicolumn{1}{c}{ Zona } & \multicolumn{1}{c}{ Sub Zona } & \multicolumn{1}{c}{ Kecamatan } \\
\hline Perkotaan & Sub Zona A.1 & Pekalongan Kota \\
& Sub Zona A.2 & Sragi, Siwalan \\
& Sub Zona A.3 & Kajen, Karanganyar \\
Pinggiran & Sub Zona B.1 & Wonokerto, Wiradesa, \\
& & Tirto & Bojong, Wonopringgo, \\
& Sub Zona B.2 & Kedungwuni, \\
& & Karangdadap, Buaran \\
Perdesaan & Sub Zona C.1 & Wonokerto, Siwalan, \\
& & Wiradesa, Sragi, Bojong \\
& Sub Zona C.2 & Kesesi, \\
& & Wonopringgo, \\
& & Karanganyar, Lebakbarang \\
& & Kandangserang, \\
& Sub Zona C.3 & Paninggaran \\
& & Karangdadap, \\
& Sub Zona C.4 & Kedungwuni, Doro, Talun, \\
& & Petungkriono \\
\hline
\end{tabular}

Sumber: Analisis, 2015 


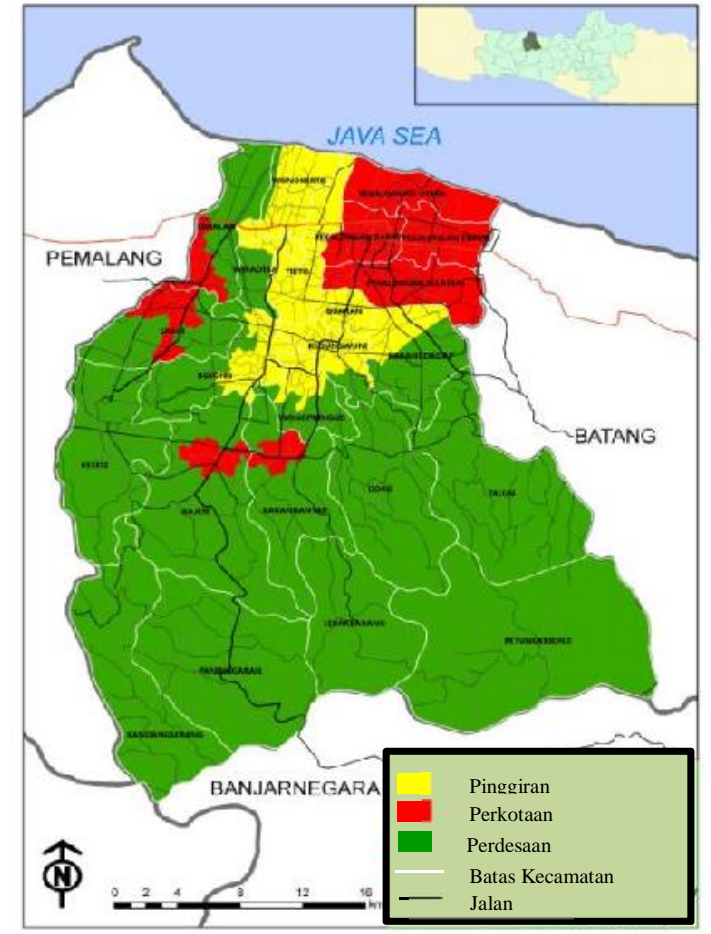

Gambar 2. Peta Deliniasi

\section{2) Karakteristik Wilayah Pekalongan}

A. Kontribusi masing-masing sektor di Pekalongan Terhadap PDRB

Wilayah Pekalongan dibagi menjadi dua yaitu Kota Pekalongan dan kabupaten pekalongan. Kota Pekalongan diidentifikasi daerah perkotaan sedangkan kabupaten Pekalongan terbagi menjadi beberapa jenis yaitu perkotaan, pinggiran dan perdesaan. Namun, walaupun berdasarkan administrasi mereka berbeda, secara fungsi mereka memiliki keterkaitan khususnya dalam penguatan potensi wilayah. Berikut dapat dilihat kontribusi masing-masing sektor terhadap PDRB di wilayah Pekalongan (Gambar 3 -4)

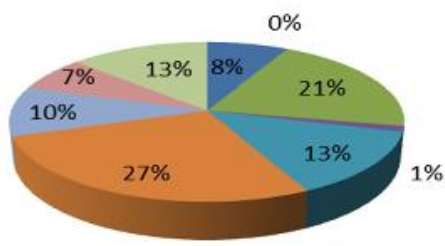

Gambar 3. Kota Pekalongan

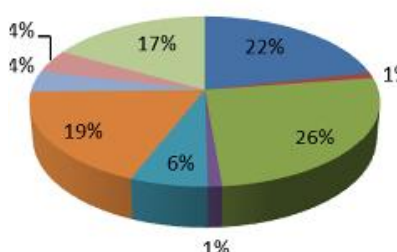

$1 \%$

Gambar 4. Kabupaten Pekalongan
- Pertanian

Eertambangan

= Industri

n Listrik, gas, air minum

- Konstruksi

nerdagangan, hotel,restauran

- Pengangkutan dan komunikasi

- Keuangan, persewaan \& jasa

- Jasa-iasa

- Pertanian

- Pertambangan

= Industri

- Listrik, gas, air minum

- Konstruksi

- Perdagangan, hotel,restauran

a Pengangkutan dan komunikasi

Keuangan, persewaan \& jasa

in Jasa-jasa
Berdasarkan gambar $3-4$ bahwa sektor unggulan yang memberikan kontribusi terhadap PDRB adalah

1. Perdagangan dan industri $\rightarrow$ Batik

2. Pertanian $\rightarrow$ perikanan dan produk hasil pertanian

Sehingga, keterkaitan desa-kota di Pekalongan fokus pada 3 sektor yaitu industri batik, perikanan dan hasil pertanian.

B. Karakteristik sektor unggulan di wilayah Pekalongan

Karakteristik wilayah Pekalongan dapat dilihat pada konteks yang lebih dalam hal fungsi dan keterkaitan dengan daerah lainnya. Fungsi dan keterkaitan ini hanya fokus pada aktifitas di tiga sektor unggulan yaitu batik, perikanan dan pertanian.

\section{a. Sektor Batik}

Pengembangan sektor batik di dukung oleh kebijakan pemerintah daerah Pekalongan. Hal ini ditertuang dalam RTRW bahwa Pekalongan memiliki visi sebagai "Kota Batik di Indonesia". Untuk memajukan sektor ini, pemerintah juga melakukan pembagian wilayah (zoning)/clustering untuk kegiatan batik. Tujuan dari zoning ini supaya menciptakan kawasan strategis dan menarik para wisatawan.
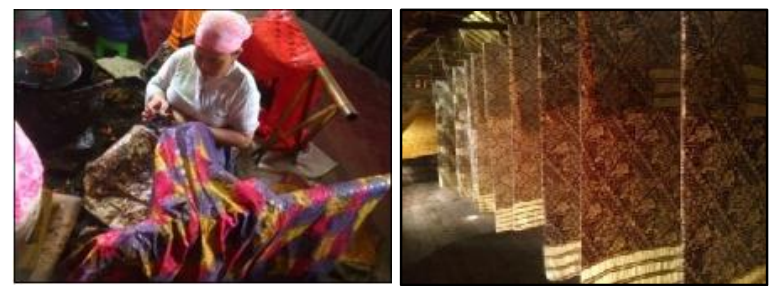

Sumber: Survei 2015

Gambar 5. Proses Batik (kiri) dan Macam macam Pola Batik di Pekalongan (kanan)

Industri batik sebagian besar terletak di daerah perkotaan seperti Setono, Kauman, Batik Wiradesa, Pantura Batik, dll. Sedangkan berdasarkan hasil survei primer untuk daerah selatan Pekalongan seperti kecamatan Paninggaran, Lebakbarang, Kandangserang dan Petungkriono produksi batik tidak ditemukan, daerah ini hanya sebagai pendistribusi batik. Selain itu, kelebihan dari batik Pekalongan tidak hanya di distribusikan di Jawa Tengah saja melainkan juga daerah lainnya seperti Jakarta, Bandung, Sumatera, dan daerah lainnya di Indonesia. Hal ini tentunya meningkatkan APBD Pekalongan 
b. Sektor Perikanan

Sektor Perikanan terletak di sebelah utara wilaya Pekalongan dan berbatasan dengan Laut Jawa. Sebagian besar aktivitas sektor perikanan terletak di TPI (Tempat Pelelangan Ikan) baik penjualan maupun pembelian. TPI di wilayah Pekalongan terletak di beberapa daerah, dimana untuk Kabupaten Pekalongan terdapat 3 TPI yaitu TPI Jambean dan TPI wonokerto untuk ikan laut sedangkan TPI Api Api untuk jenis ikan budidaya (seperti lele, bandeng, dll). Selain itu, untuk Kota pekalongan memiliki 1 TPI dimana kondisinya dapat melayani kegiatan yang lebih besar dari perikanan. Hal ini dibuktikan dari proses pendistribusian sektor perikanan yang tidak hanya di lokal dan Jawa Tengah saja melainkan ke Pemalang, Batang, Kendal, Semarang, Jakarta dan juga ke Lampung, serta dari mereka didistribusikan ke luar negeri seperti Maroko. Untuk nelayan tidak hanya dari wilayah Pekalongan melainkan juga dari luar wilayah seperti Pemalang, Batang dan Kendal.

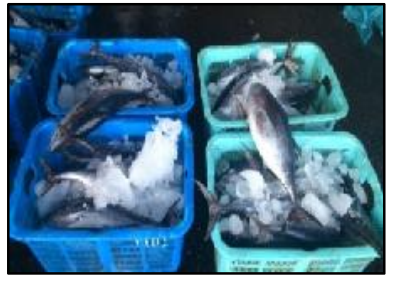

Sumber: Survei 2015

Gambar 6. Produk Perikanan di Pekalongan - Ikan Laut (kiri) dan Ikan Asin (kanan)

c. Sektor Pertanian

Sektor pertanian sebagian besar terletak di selatan Pekalongan seperti sayuran dan buahbuahan. Daerah ini di dominasi oleh aktivitas perdesaan. Sedangkan sebelah utara Pekalongan di dominasi oleh padi dan jenis tanahnya tidak dapat dimanfaatkan pada tanaman hortikultura. Hasil produk sebagian besar di distribusikan di Pekalongan, namun beberapa juga di daerah lain seperti Pemalang, batang dan kendal.
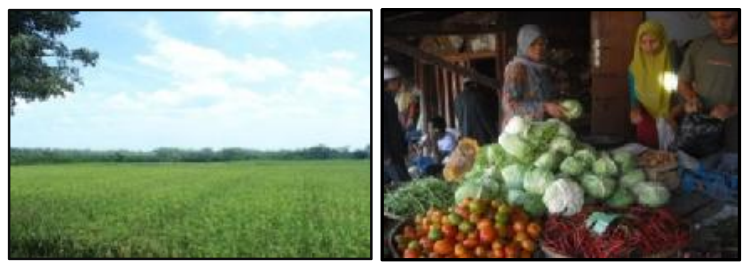

Sumber: Survei 2015

Gambar 7. Kondisi Padi (kiri) dan Produk Sayuran (kanan) di Wilayah Pekalongan
Produk pertanian ini tidak hanya di produksi di daerah lokal (Pekalongan) tetapi juga di Kabupaten Banjarnegara. Sehingga, upaya untuk mengembangkan sektor pertanian, pemerintah berencana untuk mengembangkan daerah agropolitan khususnya di kecamatan Karnganyar dan Doro. Program ini masih proses karena disangat dibutuhkan partisipasi mayarakat dan stakeholder untuk mengembangkan konsep ini

\section{3) Potensi Pola Aliran Sumberdaya Wilayah Pekalongan}

\section{A. Isu - isu Hubungan desa-kota}

Terdapat tiga sektor terkait dengan interakasi desa kota di Pekalongan yaitu sektor batik, pertanian dan perikanan. Untuk sektor batik di dominasi di kota pekalongan, sektor pertanian di kabupaten pekalongan sedangkan sektor perikanan di kawasan pesisir pekalongan yaitu tepatnya di sebelah utara pekalongan. Untuk lebih jelasnya dapat dijelaskan terkait isu-isu keterkaitan antar desa kota

\section{a. Isu-isu zona perkotaan-pinggiran}

Isu2 antar zona ini dilakukan untuk mengidentifikasi hubungan antara masing masing zona (Gambar 8)

Zona Perkotaan
1) Komoditas
- Produk batik
- Produk pertanian
- Produk perikanan
2) Tenaga kerja
- Produk batik
- Produk pertanian
- Produk perikanan

Sumber: Analisis, 2015

Gambar 8. Hubungan zona perkotaan dan pinggiran

Berdasarkan gambar 5 diketahui bahwa (1) untuk komoditas, masing-masing zona memiliki kemampuan untuk memroduksi tiga sektor (batik, perikanan dan pertanian). (2) Namun, untuk tenaga kerja hanya memiliki hubungan searah pada masing-masing sektor. Artinya, tenga kerja di zona perkotaan tidak hanya diperoleh dari masyarakat lokal di perkotaan melainkan dari zona pinggiran. Hal ini sejalan dengan pendapat Goetz (2005) yang menyatakan terjadinya perubahan mata pencaharian di zona pinggiran disebabkan zona perkotaan lebih 
berkembang khususnya dalam peningkatan perekonomian mereka. Namun sebaliknya untuk zona pinggiran, tenaga kerja dari tiga sektor tersebut diperoleh dari masyarakat lokal.

b. Isu-isu zona perkotaan - perdesaan

Berikut ini hubungan antara zona perkotaan dan perdesaan dalam pemanfaatan sumberdaya potensi yang ada di Pekalongan (Gambar 9)

Zona Perkotaan
1. Komoditas
- Produk batik
- Produk pertanian
- Produk perikanan
2. Tenaga kerja
- Produk batik
- Produk pertanian
- Produk perikanan

Sumber: Analisis, 2015

Gambar 9. Hubungan zona perkotaan dan perdesaan

Berdasarkan gambar 6 dapat di identifikasi bahwa (1) masing-masing komuditas (batik, perikanan, pertanian) dapat diproduksi dan dipasarkan di zona perkotan dan perdesaan. Sedangkan berdasarkan (2) tenaga kerja hanya memiliki hubungan satu arah hanya pada sektor batik. Untuk produk pertanian dan perikanan diperoleh dari zona pinggiran bukan dari perdesaan. Hal ini mengidentifikasikan bahwa karakteristik zona perkotaan dan pinggiran memiliki kesamaan salah satunya sebagai aktivitas industri. Hasil analisis ini dikuatkan oleh teori McGee (2008) berdasarkan lokasi spasialnya, zona pinggiran merupakan zona transisi antara zona perkotaan dan petanian, dimana karakteristik mata pencahariannya telah bergeser menjadi non-pertanian.

\section{c. Isu-isu zona pinggiran - perdesaan}

Hubungan antara zona pinggiran dan perdesaan dapat dijelaskan pada gambar 7

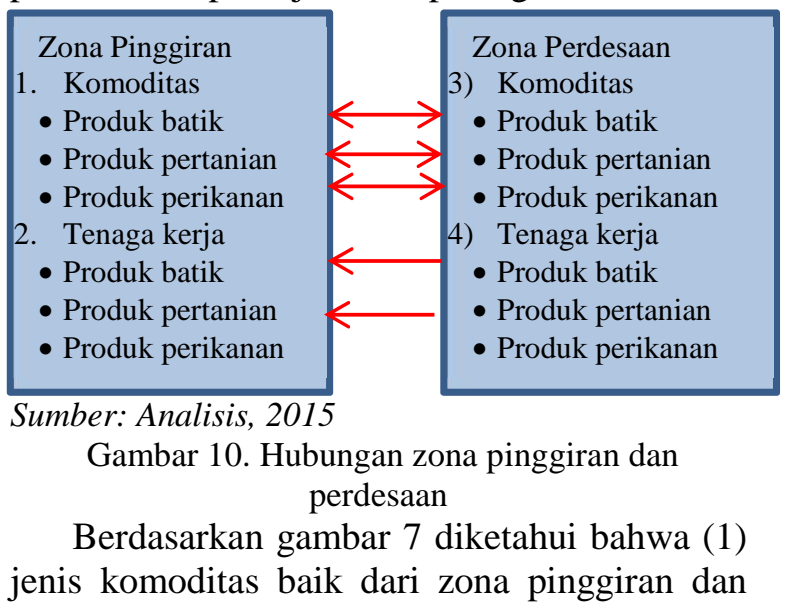

zona perdesaan dapat memproduksi tiga sektor industri tersebut (2) sedangkan untuk tenaga kerja hanya memiliki hubungan searah pada sektor batik dan pertanian, artinya tenaga kerja pada dua sektor ini selain dari masyarakat pinggiran sendiri juga di supply oleh masayarakat perdesaan. Fenomena ini merupakan dampat terjadinya perubahan lahan yang mempengaruhi bergesernya mata pencaharian di zona pinggiran. Seperti yang dijelaskan Su-Shiliang et al. (2010) bahwa perubahan lahan di zona pinggiran yang disebabkan oleh area industri dan permukiman berdampak pada penurunan kuantitas lahan pertanian. Sehingga kecenderungan untuk bekerja di perdesaan kurang diminati oleh masyarakat.

\section{B. Keterkaitan desa kota melalu analisis potensi pola aliran (Potential flow analysis)}

Analisis pola aliran (flow analysis) digunakan untuk mengetahui pola hubungan antara zona satu dengan zona lainnnya. Analisis yang digunakan fokus pada tiga sektor yaitu batik, perikanan dan pertanian sedangkan untuk tipe pola hubungan desa kota diilihat dari tenaga kerja dan jenis komoditas.

\section{a. Zona Perkotaan}

Terdapat dua jenis keterkaitan yang terjadi di sub zona A.1. Pertama, pendistribusian komoditas dan kedua tenaga kerja. Sub zona A.1 merpakan inti dari daerah perkotaan yang memiliki keterkaitan tertinggi ke sub zona lainnya khususnya di sektor batik. Hal ini disebabkan pusat pendistribusian batik dengan pemasaran terbesar di Setono. Untuk produser batik berasal dari beberapa sub zona seperti B.1; B.2; C. 1 dan C.2 dimana produk dari sub zona ini di distribusikan ke sub zona A.1. Untuk lebih jelasnya terkait hubungan antara sektor lainnya juga dapa dilihat pada tabel 3

\section{b. Zona Pinggiran}

Zona pinggiran dibagi menjadi dua sub zona yaitu B.1 (Kecamatan Wonokerto, Wiradesa, dan Tirto); B.2 (Kecamatan-Bojong, Wonopringgo, Kedungwuni, Karangdadap dan Buaran). Sub zona B.1 meruapak pusat sektor perikanan dimana di daerah ini memiliki 2 TPI (Tempat Pelelangan Ikan). Bedasarkan hasil analisis sub zona B.1 hanya mendistribusikan $6 \%$ dari hasil produk ikan laut ke sub zona A.2, A.3, B.1, C.1, C.2, C.3 dan C.4. Selain itu, B.1 juga memproduksi produk olahan ikan asin sebesar 30\% dari total ikan asin. Ikan asin ini 
telah di distribusikan ke sub-zona A.1, A.2, A.3 dan B.2. Selain itu, sebagian besar potensi B.2 mendistribusikan hasil perikanan ke luar sub zona. Salah satunya pemasok tertinggi di distribusikan ke ke Kota Pekalongan sebesar $29,78 \%$. Untuk lebih jelasnya dapat dilihat pada tabel 3.

\section{c. Zona Perdesaan}

Zona pinggiran dibagi menjadi 4 sub zona Untuk sub zona C.1 terletak di utara Pekalongan dimana fokus pada pendistribusian jenis buahbuahan.
Sub zona C.2 juga memiliki keterkaitan antar sub-zona lainnya. Salah satunya sub zona C.2 menyediakan ikannya $100 \%$ ke sub zona B.1 khususnya di Wonokerto (TPI Api-Api). Untuk lebih jelasnya dapat dilihat pada tabel 3 tentang analisis pola hubungan Desa Kota.

Tabel 3. Analisis Pola Hubungan Desa Kota

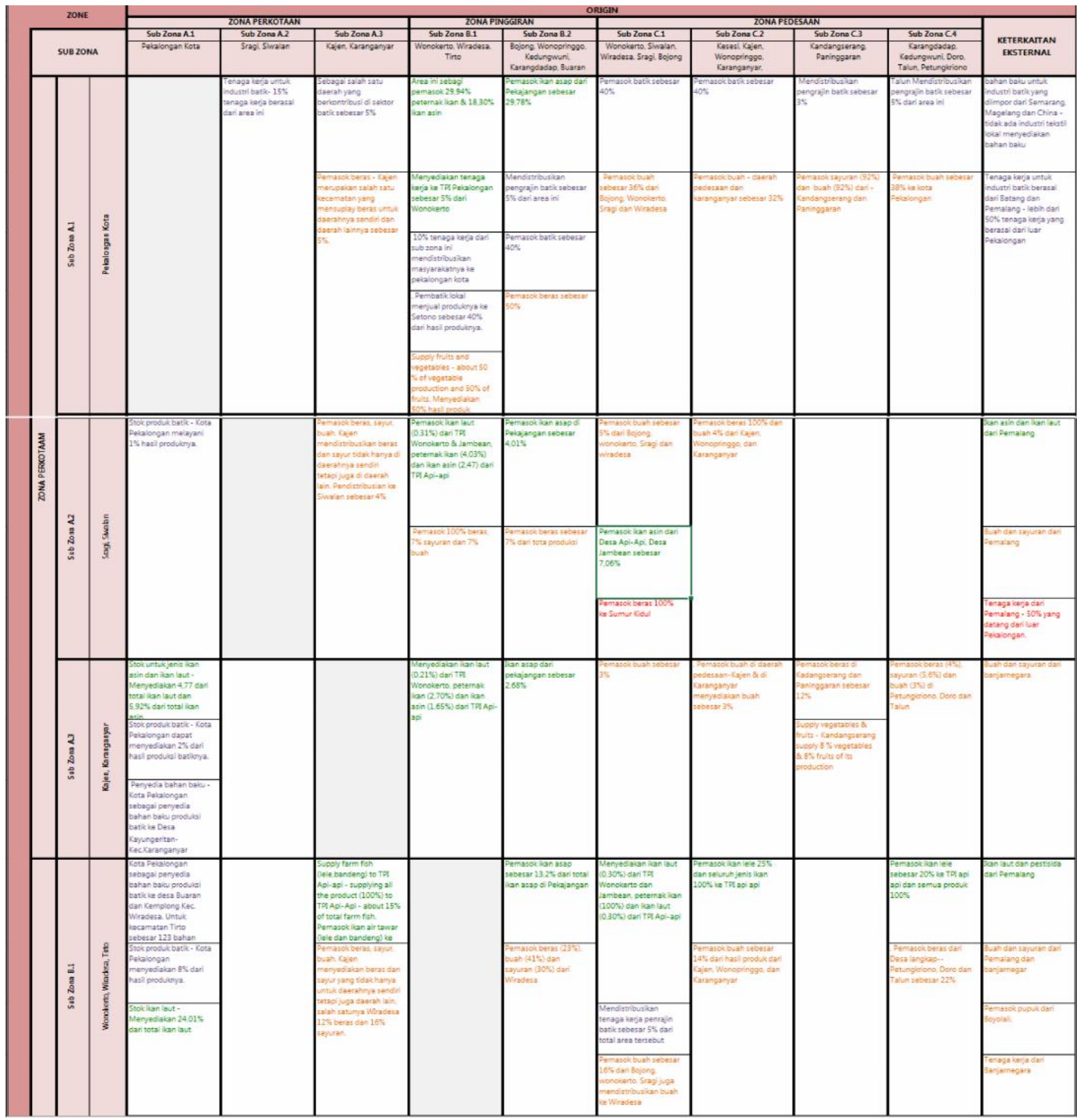


Siti Nuurlaily Rukmana dan Moch. Shofwan : Produk Lokal Sebagai Kekayaan Nusantara : Penguatan Desa-Kota Melalui Pola Aliran Sumberdaya Wilayah

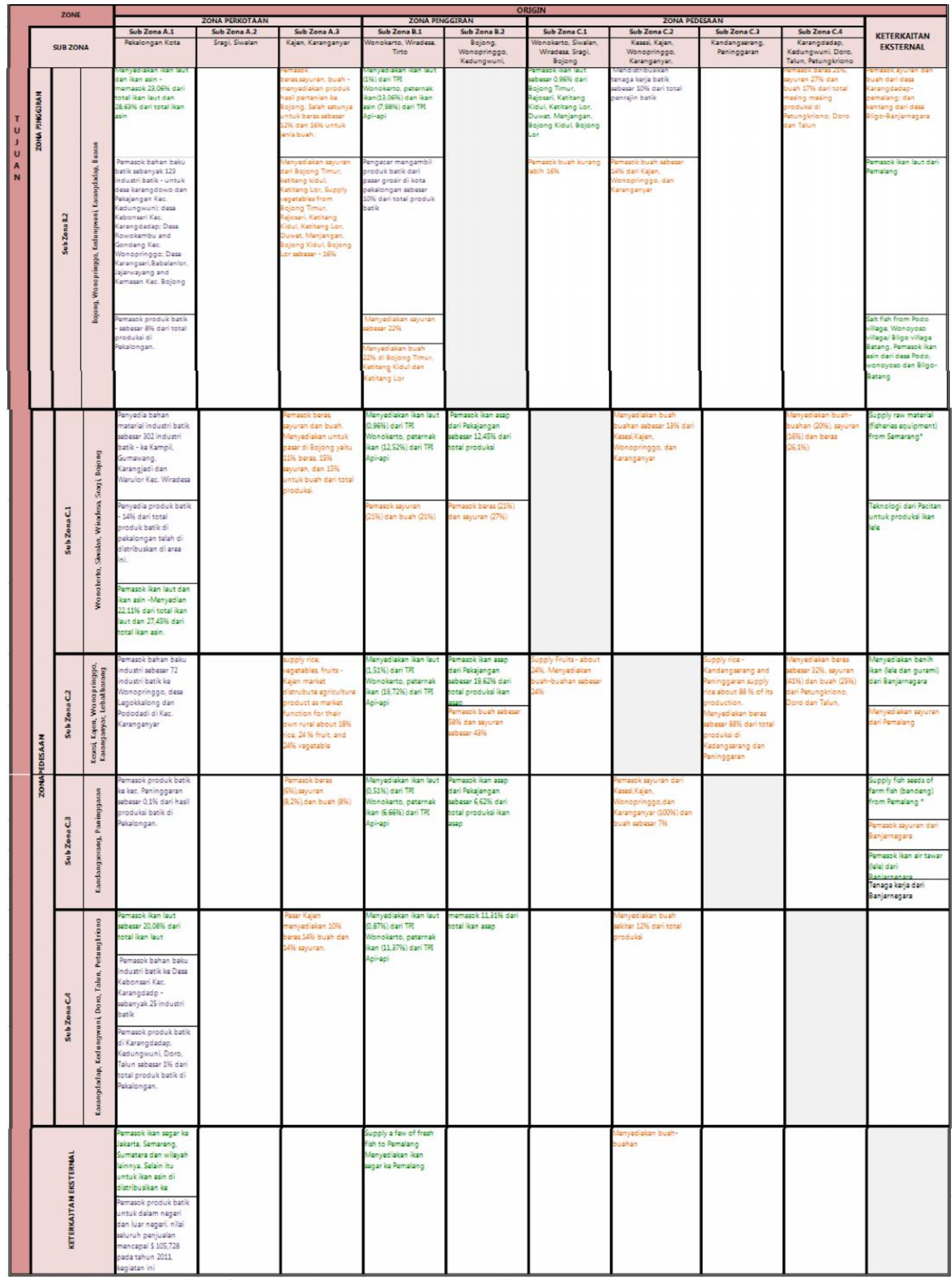




\section{KESIMPULAN}

Pengurangan laju urbanisasi salah satunya dengan cara melakukan penguatan antara desa dan kota dalam suatu wilayah. Pekalongan dibagi menjadi tiga zona yaitu perkotaan, pinggiran dan perdesaan. Untuk aktifitas zona perkotaan di dominasi oleh sektor batik, hal ini dibuktikan bahwa pemasaran di Kecamatan kajen sebagai pusat pola distribusi (distribution flow) produk bati ke kecamatan lainnya di wilayah Pekalongan dan sekitarnya.. Namun untuk pengrajin batik sendiri $\pm 50 \%$ berasal dari ekternal wilayah pekalongan (misalnya Pemalang). Selain itu, untuk sektor perikanan sebagian besar terletak di zona pinggiran (Wonokerto, Wirdesa dan Tirto) dimana pada sub zona ini terdapat dua TPI yaitu TPI
Jambean dan TIP Wonokerto sedangkan satu TPI terletak di Kota Pekalongan. Berbeda dengan zona lainnya, untuk zona perdesaan aktifitasnya di dominasi di sektor pertanian seperti jenis sayuran dan buah-buahan.

\section{UCAPAN TERIMA KASIH}

Ucapan terima kasih ditujukan kepada Program Studi Perencanaan Wilayah dan Kota, Fakultas Teknik Sipil dan Perencanaan, Universitas PGRI Adi Buana (UNIPA) Surabaya sebagai wadah pengembangan keilmuan.

\section{DAFTAR PUSTAKA}

Goetz Stephan .,James Shortle.,John Bergstrom. 2005.Land Use Problems and Conflict - causes, consequences and solutions. New York : Routledge

Lynch, Kenny. 2005. Rural Urban Interaction in Developing Countries. New York: Routledge

Mc.Gee. 2008. Managing the rural-urban transformation in East Asia in the $21^{\text {st }}$ century. Canada: Springer

Su-Shiliang., Zhenlan Jiang., Qi Zhang., Yuan Zhang. (2010). Transformation of agriculture landscape under rapid urbanization: A threat to sustainability in Hang-Ji-Hu region, China. Applied Geography, 31 (2011) 439-449. RTRW Kota Pekalongan Tahun 2009-2029. Kota Pekalongan: BAPPEKO

RTRW Kabupaten Pekalongan Tahun 2011-2031. Kabupaten Pekalongan: Bappeda

WHO, 2015. Urban Population Growth. Diakses di

http://www.who.int/gho/urban_health/situation_trends/urban_population_growth_text/en/pada tanggal 28 Mei 2016 